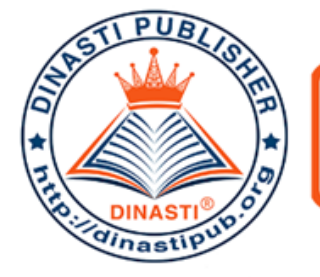

\title{
THE DIFFERENCE OF MODELS OF ENTREPRENEURSHIP INTENTION BETWEEN STUDENTS OF ECONOMIC AND BUSINESS FACULTY OF MERCU BUANA UNIVERSITY AND FACULTY OF ECONOMICS AND COMMUNICATION OF BINA NUSANTARA UNIVERSITY (COMPARATIVE STUDY)
}

\author{
M. Havidz Aima', Suta Achmad Wijaya ${ }^{2}$, Siti Rohmawati ${ }^{3}$ \\ 1) 2) 3) Mercubuana University, Jakarta, Indonesia
}

\begin{tabular}{|c|c|}
\hline $\begin{array}{l}\text { ARTICLE INFORMATION } \\
\text { Received: } 25^{\text {th }} \text { May } 2020 \\
\text { Revised: } 20^{\text {th }} \text { June } 2020 \\
\text { Issued: } 23^{\text {th }} \text { August } 2020 \\
\text { Corresponding author: First } \\
\text { Author } \\
\text { E-mail: } \\
\text { sitirohmawati286@gmail.com }\end{array}$ & $\begin{array}{l}\text { Abstract: Indonesia's labor conditions still need serious } \\
\text { attention. There are still many unemployed people who are } \\
\text { actually dominated by educated circles. The high unemployment } \\
\text { rate is also due to the large number of college graduates who } \\
\text { want to find job rather than those who can create their own jobs } \\
\text { by becoming entrepreneurs. There are many factors that } \\
\text { influence the decision of students / alumni to start a business or } \\
\text { entrepreneurship. One of program in reducing unemployment } \\
\text { and increasing employment is entrepreneurship education. } \\
\text { Mercu Buana University and Bina Nusantara University are } \\
\text { among the tertiary institutions in Indonesia that provide } \\
\text { entrepreneurship education. This study aims to determine the } \\
\text { effect of internal and external factors on entrepreneurship } \\
\text { intention mediated by entrepreneurship cognition at Mercu } \\
\text { Buana University and Bina Nusantara University. This study } \\
\text { uses a quantitative approach with data analysis in testing the } \\
\text { measurement model and testing the structural model using } \\
\text { SmartPLS software version } 3.2 .7 \text {. The results of the study can } \\
\text { show that internal factors and external factors have a significant } \\
\text { positive effect on entrepreneurship cognition and } \\
\text { entrepreneurship intention in Mercu Buana University and Bina } \\
\text { Nusantara University, if internal factors and external factors are } \\
\text { mediated by entrepreneurship cognition variable, the effect } \\
\text { becomes significant on entrepreneurship intention. In addition, } \\
\text { entrepreneurship cognition also has a significant positive effect } \\
\text { on entrepreneurship intention in Mercu Buana University and } \\
\text { Bina Nusantara University Internal Factors, External Factors, } \\
\text { Keywords: Intention, Entrepreneurship Education, } \\
\text { Entrepreneurship In } \\
\text { Entrepreneurship Cognition. }\end{array}$ \\
\hline
\end{tabular}




\section{INTRODUCTION}

Indonesia's labor conditions still need serious attention. This can be seen from the high rate of open unemployment. According to BPS 2019 data, the open unemployment rate in Indonesia is as much as 5.01 percent of the existing workforce of 6.82 million people. One of the highest unemployment is 6.24 percent of university graduates. In other words, there is an offer of university graduates who are not absorbed by the workplace (BPS 2019).

According the data, it is very unpleasant, college graduates who are supposed to be agents of change become unemployed. The large amount of unemployment could be due to the imbalance between the profile of university graduates and the qualifications of ready-to-use labor needed by the company, so that, Indonesia is always a surplus of educated workers absorbed by industry every year (Kompas 2016). The high unemployment rate is also due to the large number of college graduates who want to find work rather than those who can create their own jobs by becoming entrepreneurs. This is proven by a survey of the Indonesian Young Entrepreneurs Association (BPP Hipmi) survey that 83 percent of student respondents tend to want to become employees. Meanwhile, only 4 percent were interested in becoming entrepreneurs (Republika 2016). The previous research results were also strengthened by pre-research which concluded that $72.3 \%$ of students were interested in becoming employees after graduation, not being entrepreneurs,

There are many factors that influence the decision of students / alumni to start a business or entrepreneurship. These factors are generally categorized into two types, namely internal factors and external factors. Internal factors are factors that exist in a person who drives to become anentrepreneur. While external factors are factors that are outside oneself that encourage being an entrepreneur.The results of the pre-study conducted concluded that there are several dominant factors that influence students' interest in entrepreneurship, which are shown in Table 1

Table 1. Sequence of Factors Affecting Entrepreneurship Intention

\begin{tabular}{|c|l|l|}
\hline Order & Dimension/indicators & Variable Category \\
\hline 1 & Family Support Businness Ability & Entrepreneurship Cognition \\
\hline 2 & Capital & External Factor \\
\hline 3 & Experience Personal Character & Internal Factor \\
\cline { 2 - 3 } & Social Support & Entrepreneurship Cognition \\
\hline 4 & Peer Support & Entrepreneurship Cognition \\
\hline 5 & Entrepreneurship Education & External Factor \\
\hline 6 & Peer Environment & External Factor \\
\hline 8 & Social Environment & External Factor \\
\hline 9 & Family Environment & Internal Factor \\
\hline
\end{tabular}

Source : Researcher processed data (2020)

One solution to reduce the number of educated unemployed is to prepare college graduates to become resilient entrepreneurs in the future through entrepreneurship education. During this time at Mercu Buana University and Bina Nusantara University taught entrepreneurship programs to prepare graduates to become reliable entrepreneurs. However, there has not been a comparative study analyzing the factors that influence entrepreneurship intention in the students of the two universities.

Based on this, the researcher is interested to find out more about it, so the topic to be investigated is "Differences in Entrepreneurship Intention Model between Students of the Faculty of Economics and Business at Mercu Buana University and Bina Nusantara University (Comparative Study)". 


\section{LITERATURE REVIEW \\ Entrepreneurship}

Entrepreneurship is defined as a creative and innovative ability that is used as a basis, tips, resources, processes and struggles to create value-added goods and services carried out with courage to face risks. In terms of the characteristics of the actors, entrepreneurs are those who establish, manage, develop and institutionalize their own companies. Entrepreneurs are those who can create work for others by self-help. This definition assumes that everyone who has normal abilities can be an entrepreneur as long as he wants and has the opportunity to learn and try (Aima et al 2015)

\section{Internal Factor}

Internal factors are factors that exist in a person who drives to become an entrepreneur. Dimensions of internal factors in this study, namely: personal character and experience (Santoso et al 2017). Many experts proved that certain characteristics tend to be related to entrepreneurship intention. Some personal characteristics chosen in this study are internal self-control, need for achievement, self-confidence and also risk tolerance (Mat et al 2015, Karabulut 2016, Din et al 2015, Galanakis 2016)

Internal self-control shows that a person believes that his decision can determine his life. The need for achievement shows someone's drive to be able successfully build a business in a competitive market. Self-confidence, namely individual self-perception of their skills and abilities.

Risk tolerance is the courage to take career, financial, family and reputation risks when deciding to build their own business (Mat et al 2015, Karabulut 2016, Din et al 2015, Galanakis 2016)

Entrepreneurship experience as a basis for entrepreneurship can cause different impacts on entrepreneurship interests, can have positive or negative impacts. The experience in question is the personal experience and experience of others in running a business. The successes and failures experienced will stabilize or fade out positive or negative images about entrepreneurship which will ultimately influence entrepreneurship interest. (Newbery et al 2018, Tuan et al 2019)

\section{External Factor}

External factors are factors that are outside oneself that drive entrepreneurs. The dimensions of external factors in this study, namely capital and entrepreneurship education. Capital is an important component that is considered before starting a business. there are two types of capital that affect one's intention to entrepreneurship, namely money capital and the availability of strategic locations (capital places) (Effendy 2018, Rahmadi et al 2016)

Entrepreneurship education has the effectiveness to increase entrepreneurship intention. There are two types of categories in entrepreneurship education, namely as part of the education curriculum or as extracurricular activities (additional). Both are expected to improve entrepreneurship competence for students. (Sugiarto et al 2015, Suarjana et al 2017, Din et al 2015, Laguia et al 2019, Putri 2017 and Lackeus 2014).

\section{Entrepreneurship Cognition}

Entrepreneurship cognition encompasses broad thinking centered on the discovery, exploration and testing of one's potential to be an entrepreneur. Individuals continue to explore what it's like to be an entrepreneur in various ways. The more individuals believe in their ability to successfully carry out the duties and roles of an entrepreneur, then usually they will tend to take entrepreneurship actions. Dimensions used in entrepreneurship cognition are attitudes toward entrepreneurship, subjective norms and behavioral control perceptions.Attitudes toward entrepreneurship are individual beliefs about how desirable or undesirable the outcome of a business is. Subjective norms are a person's perception of the support that will be received in doing something, whether from family, friends or colleagues in general. Behavioral control is the perception of ease or difficulty in performing a behavior (Tuan et al 2019, Ambad et al 2016, 
Saiman 2016, Bogatyrevaa 2019, Anas 2018, Galanaki 2016, Rahmadi 2016, Walipah et al 2016, Suarjana 2017, Pratiwi et al 2016, Laguia et al 2019, Ligouri et al. 2018)

\section{Entrepreneurship Intention}

In general, 'intention' can be interpreted as a relatively settled tendency for someone to feel attracted to a particular field and feel happy to be involved in it. Individuals who are have intention in becoming entrepreneurs generally feel attracted and tend to be happy with the entrepreneurship profession. Individuals who are interested in becoming entrepreneurs have a cognitive understanding of the benefits, challenges, and risks that will be faced (cognitive), feel happy with their choices (affective), and will act (conative) as he believes. Intention can be seen from the desire (Desire), self- prediction in the future (Self Prediction) and also the tendency of the desired action (Behavioral Intention). Entrepreneurship intention can be seen from the ability of someone to see themselves as entrepreneurs in the future, planning to establish a new business in future, preferring a career as a entrepreneur after graduation, would rather be an entrepreneur than an employee and also can expect to start their own business within a few years after completing studies. (Pratiwi et al 2016, Santoso et al 2017, Tuan 2019).

\section{Framework}

One solution to reduce the number of educated unemployed is to prepare college graduates to become resilient entrepreneurs in the future through entrepreneurship education. During this time at Mercu Buana University and Bina Nusantara University taught entrepreneurship programs to preparegraduates to become reliable entrepreneurs. On the other hand, there are many factors that influence the decision of students / alumni to start a business or entrepreneurship.

Based on the description above, the researchers set a number of variables that will be examined later, consisting of an independent variable (X), namely Internal Factors (X1) including Personal Characteristics and Experiences and External Factors (X2) including Capital and Entrepreneurship Education. Whereas, for the dependent variable (Y) namely Entrepreneurship Cognition (Y1) includes Attitudes toward Entrepreneurship, Subjective Norms and Perception of Behavioral Control and Entrepreneurship Intention (Y2) include Desire, Self-Prediction in the Future and also the Tendency of Desired Actions. So, the framework in this study is as follows:

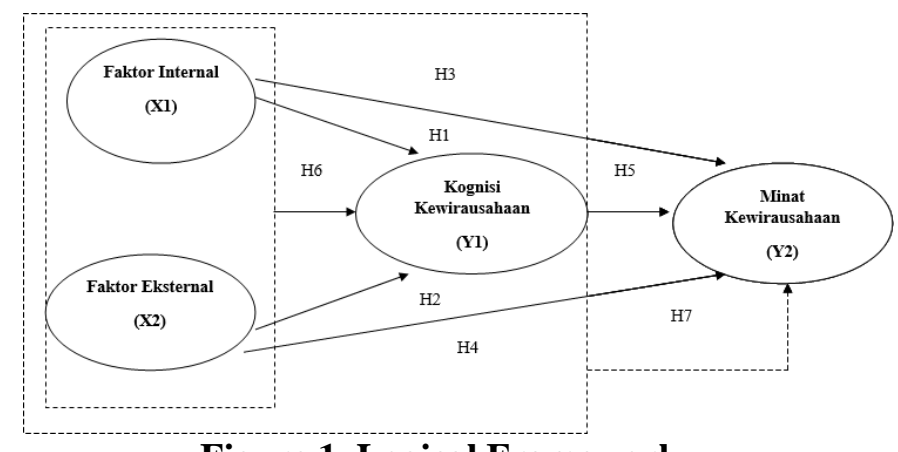

Figure 1. Logical Framework

Referring to the framework above, this study wants to find out and explain whether Internal Factors that have a significant effect on entrepreneurship cognition at Mercu Buana University and Bina Nusantara University, External Factors have a significant effect on entrepreneurship cognition at Mercu Buana University and Bina Nusantara University, Internal Factors have a significant effect on entrepreneurship intention in Mercu Buana University and Bina Nusantara University, External Factors have a significant effect on entrepreneurship intention in Mercu Buana University and Bina Nusantara University, Entrepreneurship Cognition has a significant effect on entrepreneurship intention in Mercu Buana University and Bina Nusantara University, Internal Factors and External Factors have a significant effect on entrepreneurship cognition at Mercu Buana University and Bina Nusantara University, Internal Factors, External Factors, and entrepreneurship cognition have a significant effect on entrepreneurship intention at Mercu University Buana and Bina Nusantara 
University, Entrepreneurship Cognition significantly mediates the influence of internal and external factors on entrepreneurship intention at Mercu Buana University and Bina Nusantara University.

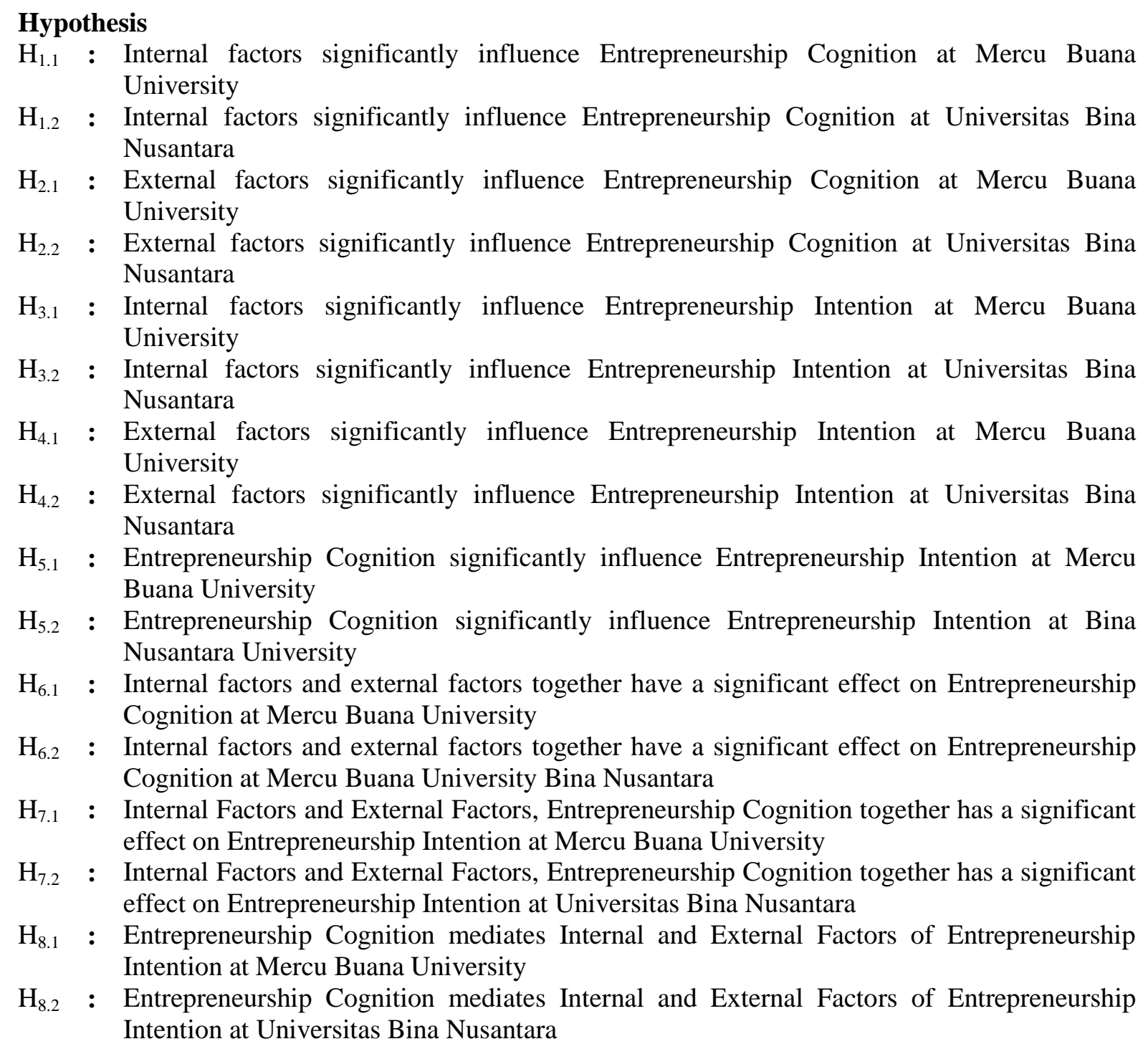

\section{RESEARCH METHODS}

This type of research used in this research is quantitative research. The data used in this study are primary data in the form of survey results. In order to collect complete, significant and complementary data, in addition to primary data, researchers also use secondary data. The result of the study are presented simply so that it can be understood, can describe and analyze the influence of the independent variables (independent) on the dependent variable (dependent). In addition, the authors make this research to describe and analyze the correlation between the independent variable (independent) with the dependent variable (dependent). The analysis used in this study is to use relevant statistical data to test hypotheses. So that the data obtained in this study can provide a clear picture of the object under study and later a conclusion can be made. The research variables described in terms of dimensions, indicators and question items as data collection instruments can be seen in Table 1. 
Table 1. Operational Variable

\begin{tabular}{|c|c|c|c|}
\hline Variabel Type & Dimension & Indicator & No. Item \\
\hline \multirow{6}{*}{$\begin{array}{c}\text { Internal Factor } \\
\text { (X1) } \\
\text { (Din } d k k 2015 \\
\text { Tuan } d k k 2019 \\
\text { Periyadi } d k k \text { 2019) }\end{array}$} & Personal Character & a) Internal Locus Control & $1-2$ \\
\hline & & b) Need Achievement & $3-4$ \\
\hline & & Self Efficacy & $5-6$ \\
\hline & & d) Risk Tolerance & $7-8$ \\
\hline & Experience & a) $\quad$ Personal Experience & $9-10$ \\
\hline & & b) The experience of others & $11-12$ \\
\hline \multirow{5}{*}{$\begin{array}{c}\text { External Factor } \\
\text { (X2) } \\
\text { (Rahmadi } d k k 2016, \\
\text { Putri } 2017 \\
\text { Lackeus } 2014 \\
\text { Periyadi } d k k \text { 2019) }\end{array}$} & Capital & a) Money Capital & $13-14$ \\
\hline & & b) Location Capital & $15-16$ \\
\hline & 2) $\quad$ Entrepreneurship & Education curriculum & $17-18$ \\
\hline & Education & b) Extracurricular & \\
\hline & & & $19-20$ \\
\hline \multirow{7}{*}{$\begin{array}{c}\text { Entrepreneuship } \\
\text { Cognition } \\
\text { (Y1) } \\
\text { (Fuller } d k k 2018 \\
\text { Tuan } d k k 2019 \\
\text { Esfandiara } d k k \quad 2019 \text { ) }\end{array}$} & 1) Attitude toward & Trust in result & $21-22$ \\
\hline & entrepreneurship & Evaluation of result & $23-24$ \\
\hline & 2) Subjective Norms & a) Family & $25-26$ \\
\hline & & b) Friend & $27-28$ \\
\hline & & c) Colleagues & $29-30$ \\
\hline & 3) Perception control & Ability to start business & $31-32$ \\
\hline & behavior & b) Ability to develop businness & $33-34$ \\
\hline \multirow{5}{*}{$\begin{array}{c}\text { Entrepreneurship } \\
\text { Intention } \\
\text { (Y2) } \\
\text { (Tuana } d k k 2019 \\
\text { Esfandiara } d k k \text { 2019) }\end{array}$} & 1) Desire & Purpose & 35 \\
\hline & & b) Determination & 36 \\
\hline & 2) Self Prediction & $\begin{array}{ll}\text { a) Decision } \\
\text { b) Seriousness }\end{array}$ & $\begin{array}{l}37 \\
38\end{array}$ \\
\hline & 3) Behaviour Intention & Readines & 39 \\
\hline & & Totality & 40 \\
\hline
\end{tabular}

Source : Researcher processed data (2020)

\section{Population and Sample}

The population in this study Undergraduate Student of the Faculty of Economics and Business at Mercu Buana University and Undergraduate Student at the Faculty of Economics and Communication at Bina Nusantara University. This study uses the Hair formula in determining the number of samples, i.e. the number of indicators multiplied by 5 to 10 , so that the number of samples used in this study is 120 samples (the calculation results are obtained from the multiplication of number indicators multiplied by 5 times. Each university is represented by a sample with a total of 60 people per university.The sampling technique used was Probability Sampling with the type of purposive sampling in which each population element was deliberately chosen to be the subject of research.

\section{Data Analysis}

Data analysis method used in this research is to use SmartPLS software version 3.2.7. Partial Least Square (PLS) is a study of structural equations on the basis of variance which together test the measurement model and test the structural model. To test the validity and reliability is carried out using a measurement model, while for the causality test is carried out using a structural model. 


\section{RESEARCH RESULTS AND DISCUSSION \\ Respondent Characteristic}

Characteristics of respondents in this study, presented in table 2 as follows:

Table 2. Number and Percentage of Respondent Categories

\begin{tabular}{|c|c|c|c|c|c|c|}
\hline \multirow{2}{*}{ No } & \multirow{2}{*}{ Category } & \multirow{2}{*}{ Option } & \multicolumn{2}{|c|}{$\begin{array}{l}\text { Mercu Buana } \\
\text { University }\end{array}$} & \multicolumn{2}{|c|}{$\begin{array}{c}\text { Bina Nusantara } \\
\text { University }\end{array}$} \\
\hline & & & $\begin{array}{c}\text { Total } \\
\text { (person) }\end{array}$ & $\begin{array}{l}\text { Percentage } \\
(\%)\end{array}$ & $\begin{array}{c}\text { Total } \\
\text { (person) }\end{array}$ & $\begin{array}{l}\text { Percentage } \\
(\%)\end{array}$ \\
\hline \multirow{2}{*}{1} & \multirow{2}{*}{ Sex } & Male & 35 & $58 \%$ & 20 & $33 \%$ \\
\hline & & Female & 25 & $42 \%$ & 40 & $67 \%$ \\
\hline \multirow{6}{*}{2} & \multirow{6}{*}{ Age } & 18 & 27 & $39 \%$ & 3 & $5 \%$ \\
\hline & & 19 & 18 & $28 \%$ & 27 & $45 \%$ \\
\hline & & 20 & 2 & $3 \%$ & 19 & $32 \%$ \\
\hline & & 21 & 3 & $5 \%$ & 9 & $15 \%$ \\
\hline & & 22 & 0 & $0 \%$ & 0 & $0 \%$ \\
\hline & & $>22$ & 14 & $23 \%$ & 2 & $3 \%$ \\
\hline \multirow{7}{*}{3} & \multirow{7}{*}{ Semester } & 1 & 60 & $100 \%$ & 3 & $5 \%$ \\
\hline & & 2 & 0 & $0 \%$ & 0 & $0 \%$ \\
\hline & & 3 & 0 & $0 \%$ & 34 & $57 \%$ \\
\hline & & 4 & 0 & $0 \%$ & 0 & $0 \%$ \\
\hline & & 5 & 0 & $0 \%$ & 18 & $30 \%$ \\
\hline & & 6 & 0 & $0 \%$ & 1 & $2 \%$ \\
\hline & & 7 & 0 & $0 \%$ & 4 & $7 \%$ \\
\hline \multirow{2}{*}{4} & \multirow{2}{*}{ Profession } & Doesn't Work & 51 & $85 \%$ & 54 & $90 \%$ \\
\hline & & Work & 9 & $15 \%$ & 6 & $10 \%$ \\
\hline \multirow{3}{*}{5} & \multirow{3}{*}{$\begin{array}{l}\text { Parent Profession } \\
\text { (Father) }\end{array}$} & Employee & 22 & $42 \%$ & 22 & $37 \%$ \\
\hline & & Entrepreneur & 33 & $30 \%$ & 33 & $55 \%$ \\
\hline & & Other & 5 & $28 \%$ & 5 & $8 \%$ \\
\hline \multirow{4}{*}{6} & \multirow{3}{*}{$\begin{array}{l}\text { Parent Profession } \\
\text { (Mother) }\end{array}$} & Employee & 14 & $23 \%$ & 20 & $33 \%$ \\
\hline & & Entrepreneur & 6 & $10 \%$ & 6 & $10 \%$ \\
\hline & & Other & 40 & $67 \%$ & 34 & $57 \%$ \\
\hline & Amount Per & gory & 60 & $100 \%$ & 60 & $100 \%$ \\
\hline
\end{tabular}

Source : Researcher processed data (2020)

Descriptive Statistical Analysis of Research Variables

The descriptive summary of the research variables is presented in table 3 as follows:

Table 3. Descriptive Summary of the Value of Research Variables

\begin{tabular}{lcc}
\hline Variable & Mercu Buana University & Bina Nusantara University \\
\hline Internal Factor & 4.02 & 3.98 \\
\hline External Factor & 3.74 & 3.60 \\
\hline Entreprenurship Cognition & 3.76 & 3.59 \\
\hline Entreprenurship Intention & 4.00 & 3.71 \\
\hline Source : Researcher processed data (2020) & &
\end{tabular}

Table 3 shows the results of measuring variables using a linkert scale (rating range from 1 to 5 , number 1 indicates disagreement and 5 indicates agreement). Table 3 shows the assessment of personal characteristics and business experiences of respondents at Mercu Buana University can support to become entrepreneurs, but the personal characteristics and business experiences of respondents at Bina Nusantara University do not optimally support being able to become entrepreneurs.

Table 3 shows that the assessment of entrepreneurship education at Mercu Buana University and Bina Nusantara University has not been able to optimally support entrepreneurship. This can be seen 
in the final value of less than 4 which is a symbol of disagreement that the entrepreneurship education obtained can support being an entrepreneur.

Table 3 shows the general evaluation of respondents, both at Mercu Buana University and Bina Nusantara University, regarding the choice to become an entrepreneur is still not appropriate by considering the potential results obtained, the support obtained and the ability to start and develop a business. This can be seen in the final value of less than 4 which is a symbol of disagreement that entrepreneurship is the right career choice that will provide satisfaction and profit, as well as disapproval for getting the relationship support for entrepreneurship choices and also disapproval of his own ability to start and develop a business.

Table 3 shows that in general respondents at Mercu Buana University have shown a strong determination to become entrepreneurs in earnest and totality in becoming entrepreneurs. On the other hand, respondents at Bina Nusantara University have not shown a strong determination to be entrepreneurs in earnest and totality in becoming entrepreneurs. This can be seen in the final value of less than 4 which is a symbol of disagreement that the respondent is determined to be an entrepreneur and is ready to make any effort so that his wishes are realized.

\section{Evaluation of the Reflective Measurement Model (Outer Model) or Test Indicator}

Below is a picture of the calculation results of the measurement model with SEM PLS version 3.2.7, which shows the loading factor values on the each research variable indicators. The loading factor value used in this study is $>0.5$ so that if the loading factor value $<0.5$ in the calculation results of the measurement model (outer model) will be removed from the model.

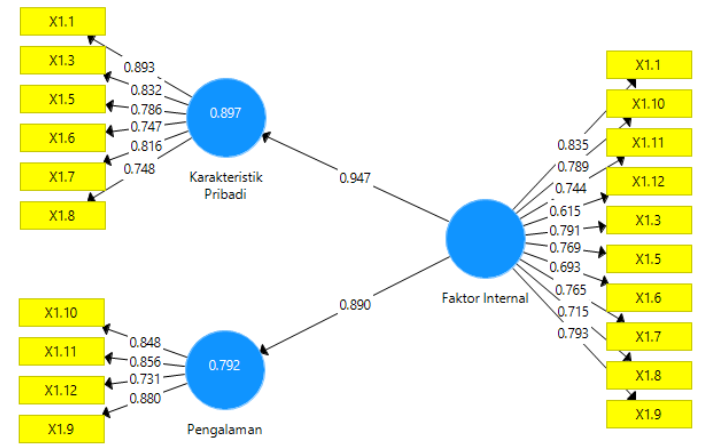

Figure 2. Loading Factor Value of Internal Factors at Mercu Buana University

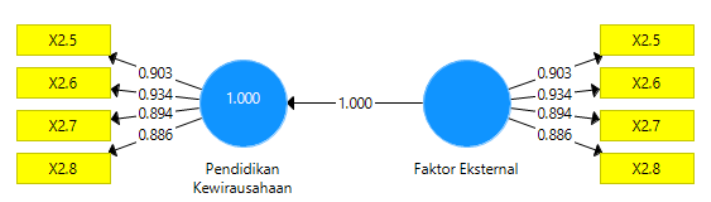

Figure 4. Loading Factor Value of External Factors at Mercu Buana University

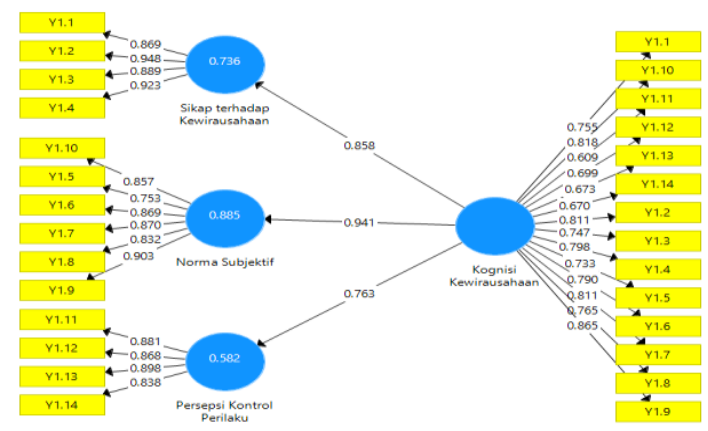

Figure 6. Loading Factor Value of Entrepreneurship Cognition at Mercu Buana University

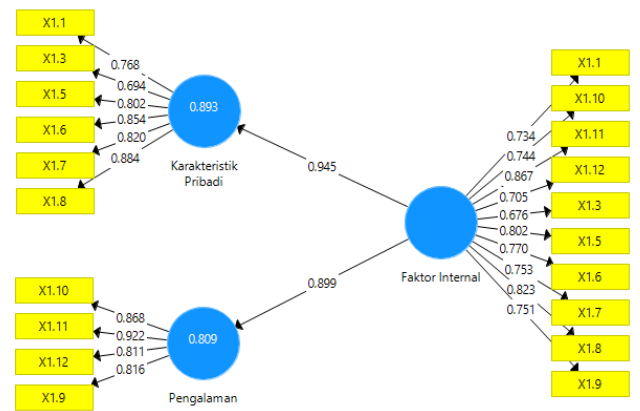

Figure 3. Loading Factor Value of Internal Factors at Bina Nusantara University

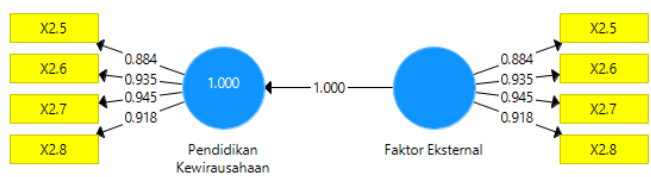

Figure 5. Loading Factor Value of External Factors at Bina Nusantara University

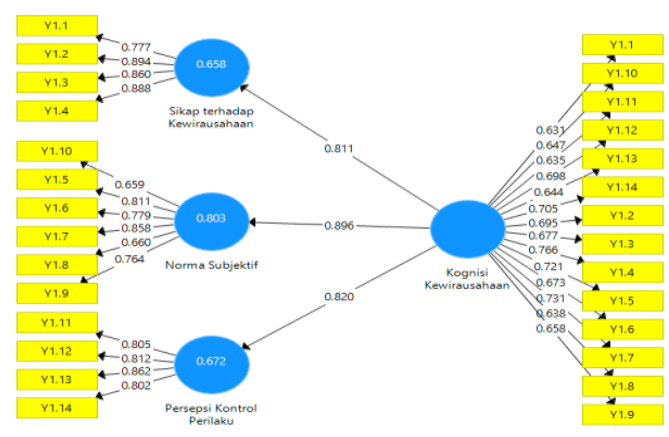

Figure 7. Loading Factor Value of Entrepreneurship Cognition at at Bina Nusantara University 


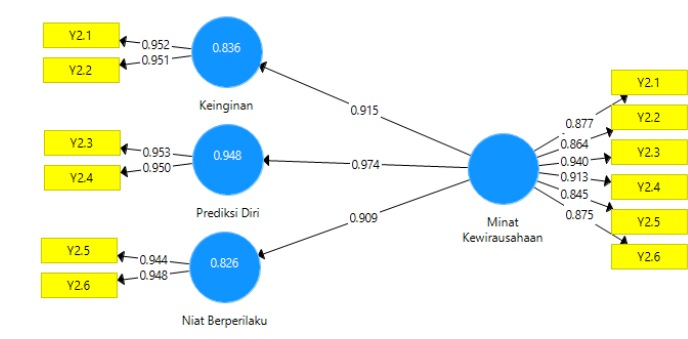

Figure 8. . Loading Factor Value of Entrepreneurship Intention Variables at Mercu Buana University

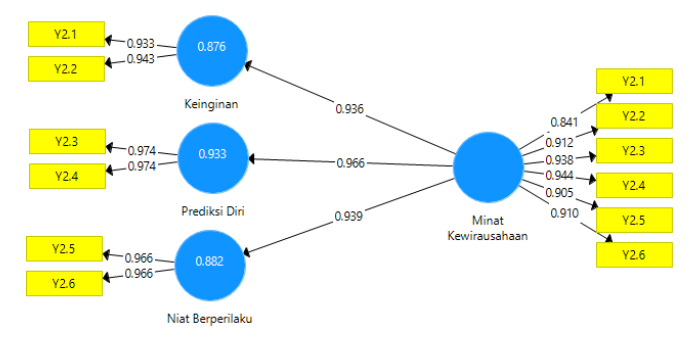

Figure 9. Loading Factor Value of Entrepreneurship Intention Variables at Bina Nusantara University

Evaluation of convergent validity from the examination of Average Variance Extracted (AVE) illustrates the great variety of manifest variables that can be possessed by latent constructs. The greater the diversity of manifest variables that can be contained by latent constructs, the greater the representation of manifest variables to their latent constructs. The term Manifest Variable is often interpreted as an indicator. AVE value must be greater than 0.5. Evaluation of convergent validity from the examination of internal consistency reliability can be seen from the value of Cronbach's Coefficient Alpha (CA) and Composite Reliability (CR) which shows the consistency value of each indicator in measuring its construct. Expected CA and CR values are>0.7. The measurement results for AVE, CA and CR meet the existing requirements and can be seen in Table 4.

Evaluation of convergent validity from the examination of Average variance extracted (AVE) illustrates the magnitude of variance or diversity of manifest variables that can be owned by latent constructs, the greater the variance or diversity of variable manifests that can be contained by latent constructs, the greater the representation of variable manifests towards its latent construct. Evaluation of convergent validity from the examination of Average Variance Extracted (AVE) can be seen from the value of AVE based on the results of data processing with SmartPLS version 3.2.7 which is in Table 4.

Table 4. Average Variance Extracted (AVE), Cronbach's Coefficient Alpha (CA) dan Composite Reliability (CR)

\begin{tabular}{|c|c|c|c|c|c|c|}
\hline \multirow{2}{*}{ Variable } & \multicolumn{3}{|c|}{ Mercu Buana University } & \multicolumn{3}{|c|}{ Bina Nusantara University } \\
\hline & AVE & $\mathrm{CA}$ & $\mathrm{CR}$ & AVE & $\mathrm{CA}$ & CR \\
\hline Internal Factor & 0.565 & 0.914 & 0.929 & 0.583 & 0.916 & 0.930 \\
\hline Eksternal Factor & 0.664 & 0.926 & 0.947 & 0.549 & 0.940 & 0.957 \\
\hline $\begin{array}{l}\text { Entreprenurship } \\
\text { Cognition }\end{array}$ & 0.571 & 0.941 & 0.949 & 0.516 & 0.911 & 0.922 \\
\hline $\begin{array}{l}\text { Entrepreneurship } \\
\text { Intention }\end{array}$ & 0.785 & 0.945 & 0.956 & 0.825 & 0.958 & 0.966 \\
\hline
\end{tabular}

Source : Researcher processed data (2020)

In table 4 above it is known that the AVE value for all instruments has a AVE value> 0.5, a Cronbach's alpha value above 0.40 and composite reliability above 0.70 . So it can be concluded that the construct or variable has a good validity and reliability..

\section{Testing the Validity of Discriminant / Descriminant Validity}

The validity of the indicators on each research variable can also be done by testing the discriminant validity by checking the cross loading value ie the correlation coefficient of the indicator against its construct compared to the correlation coefficient with other constructs. The correlation coefficient value of the indicator must be greater on the construct than the other constructs. Testing results can be seen in Table 5 and Table 6. 
Table 5. Results of Discriminant Validity Testing at Mercu Buana University

\begin{tabular}{lrrrrl}
\hline Item & $\begin{array}{c}\text { Internal } \\
\text { Factor }\end{array}$ & $\begin{array}{c}\text { External } \\
\text { Factor }\end{array}$ & $\begin{array}{c}\text { Entrepreneurship } \\
\text { Cognition }\end{array}$ & $\begin{array}{c}\text { Entrepreneurship } \\
\text { Intention }\end{array}$ & Result \\
\hline X1.1 & $\mathbf{0 . 8 2 2}$ & 0.409 & 0.507 & 0.496 & Valid \\
\hline X1.3 & $\mathbf{0 . 7 7 8}$ & 0.399 & 0.520 & 0.564 & Valid \\
\hline X1.5 & $\mathbf{0 . 7 8 8}$ & 0.551 & 0.663 & 0.521 & Valid \\
\hline X1.6 & $\mathbf{0 . 7 2 3}$ & 0.563 & 0.709 & 0.542 & Valid \\
\hline X1.7 & $\mathbf{0 . 7 4 1}$ & 0.354 & 0.444 & 0.310 & Valid \\
\hline X1.8 & $\mathbf{0 . 7 1 3}$ & 0.432 & 0.598 & 0.509 & Valid \\
\hline X1.9 & $\mathbf{0 . 7 9 2}$ & 0.527 & 0.606 & 0.557 & Valid \\
\hline X1.10 & $\mathbf{0 . 7 7 1}$ & 0.399 & 0.532 & 0.561 & Valid \\
\hline X1.11 & $\mathbf{0 . 7 4 1}$ & 0.439 & 0.543 & 0.448 & Valid \\
\hline X2.5 & 0.640 & $\mathbf{0 . 9 2 5}$ & 0.737 & 0.591 & Valid \\
\hline X2.6 & 0.662 & $\mathbf{0 . 9 5 1}$ & 0.741 & 0.597 & Valid \\
\hline X2.7 & 0.514 & $\mathbf{0 . 8 7 3}$ & 0.567 & 0.392 & Valid \\
\hline X2.8 & 0.460 & $\mathbf{0 . 8 5 9}$ & 0.521 & 0.310 & Valid \\
\hline Y1.1 & 0.572 & 0.679 & $\mathbf{0 . 7 6 6}$ & 0.625 & Valid \\
\hline Y1.2 & 0.584 & 0.664 & $\mathbf{0 . 8 2 6}$ & 0.748 & Valid \\
\hline Y1.3 & 0.661 & 0.546 & $\mathbf{0 . 7 6 5}$ & 0.756 & Valid \\
\hline Y1.4 & 0.559 & 0.513 & $\mathbf{0 . 8 1 1}$ & 0.784 & Valid \\
\hline Y1.5 & 0.601 & 0.458 & $\mathbf{0 . 7 4 8}$ & 0.694 & Valid \\
\hline Y1.6 & 0.765 & 0.611 & $\mathbf{0 . 8 0 0}$ & 0.621 & Valid \\
\hline Y1.7 & 0.678 & 0.633 & $\mathbf{0 . 8 1 5}$ & 0.649 & Valid \\
\hline Y1.8 & 0.613 & 0.583 & $\mathbf{0 . 7 6 1}$ & 0.542 & Valid \\
\hline Y1.9 & 0.695 & 0.638 & $\mathbf{0 . 8 6 8}$ & 0.660 & Valid \\
\hline Y1.10 & 0.647 & 0.612 & $\mathbf{0 . 8 1 1}$ & 0.619 & Valid \\
\hline Y1.11 & 0.318 & 0.430 & $\mathbf{0 . 5 7 8}$ & 0.405 & Valid \\
\hline Y1.12 & 0.520 & 0.502 & $\mathbf{0 . 6 8 0}$ & 0.543 & Valid \\
\hline Y1.13 & 0.403 & 0.370 & $\mathbf{0 . 6 4 6}$ & 0.490 & Valid \\
\hline Y1.14 & 0.426 & 0.352 & $\mathbf{0 . 6 4 7}$ & 0.552 & Valid \\
\hline Y2.1 & 0.550 & 0.494 & 0.716 & $\mathbf{0 . 8 7 5}$ & Valid \\
\hline Y2.2 & 0.539 & 0.431 & 0.700 & $\mathbf{0 . 8 6 1}$ & Valid \\
\hline Y2.3 & 0.609 & 0.489 & 0.763 & $\mathbf{0 . 9 3 9}$ & Valid \\
\hline Y2.4 & 0.596 & 0.561 & 0.803 & $\mathbf{0 . 9 1 6}$ & Valid \\
\hline Y2.6 & 0.642 & 0.463 & 0.708 & $\mathbf{0 . 8 4 7}$ & Valid \\
\hline & 0.664 & 0.555 & 0.725 & $\mathbf{0 . 8 7 6}$ & Valid \\
\hline S0 & & & & \\
\hline
\end{tabular}

Source : Researcher processed data (2020)

Table 6. Results of Discriminant Validity Testing at Bina Nusantara University

\begin{tabular}{lccccc}
\hline Item & $\begin{array}{c}\text { Internal } \\
\text { Factor }\end{array}$ & External Factor & $\begin{array}{c}\text { Entrepreneurship } \\
\text { Cognition }\end{array}$ & $\begin{array}{c}\text { Entrepreneurship } \\
\text { Intention }\end{array}$ & Result \\
\hline X1.1 & $\mathbf{0 . 7 2 6}$ & 0.059 & 0.354 & 0.434 & Valid \\
\hline X1.3 & $\mathbf{0 . 6 8 4}$ & 0.180 & 0.475 & 0.408 & Valid \\
\hline X1.5 & $\mathbf{0 . 8 1 2}$ & 0.116 & 0.597 & 0.589 & Valid \\
\hline X1.6 & $\mathbf{0 . 7 8 9}$ & 0.017 & 0.432 & 0.378 & Valid \\
\hline X1.7 & $\mathbf{0 . 7 5 8}$ & 0.118 & 0.427 & 0.365 & Valid \\
\hline
\end{tabular}




\begin{tabular}{|c|c|c|c|c|c|}
\hline Item & $\begin{array}{l}\text { Internal } \\
\text { Factor }\end{array}$ & External Factor & $\begin{array}{c}\text { Entrepreneurship } \\
\text { Cognition }\end{array}$ & $\begin{array}{l}\text { Entrepreneurship } \\
\text { Intention }\end{array}$ & Result \\
\hline $\mathrm{X} 1.8$ & 0.820 & 0.101 & 0.487 & 0.393 & Valid \\
\hline X1.9 & 0.747 & 0.118 & 0.480 & 0.407 & Valid \\
\hline $\mathrm{X} 1.10$ & 0.753 & 0.077 & 0.520 & 0.535 & Valid \\
\hline $\mathrm{X} 1.11$ & 0.860 & 0.144 & 0.608 & 0.565 & Valid \\
\hline $\mathrm{X} 2.5$ & 0.100 & 0.879 & 0.294 & 0.088 & Valid \\
\hline $\mathrm{X} 2.6$ & 0.215 & 0.946 & 0.393 & 0.216 & Valid \\
\hline $\mathrm{X} 2.7$ & 0.139 & 0.939 & 0.243 & 0.162 & Valid \\
\hline $\mathrm{X} 2.8$ & 0.023 & 0.916 & 0.296 & 0.197 & Valid \\
\hline Y1.1 & 0.540 & 0.319 & 0.666 & 0.435 & Valid \\
\hline Y1.2 & 0.600 & 0.240 & 0.747 & 0.598 & Valid \\
\hline Y1.3 & 0.627 & 0.242 & 0.738 & 0.738 & Valid \\
\hline Y1.4 & 0.501 & 0.312 & 0.808 & 0.748 & Valid \\
\hline Y1.5 & 0.501 & 0.145 & 0.720 & 0.377 & Valid \\
\hline Y1.6 & 0.321 & -0.056 & 0.643 & 0.503 & Valid \\
\hline Y1.7 & 0.592 & 0.100 & 0.715 & 0.361 & Valid \\
\hline Y1.8 & 0.097 & 0.226 & 0.586 & 0.365 & Valid \\
\hline Y1.9 & 0.396 & 0.371 & 0.638 & 0.227 & Valid \\
\hline $\mathrm{Y} 1.10$ & 0.257 & 0.294 & 0.600 & 0.402 & Valid \\
\hline Y1.11 & 0.225 & 0.131 & 0.599 & 0.461 & Valid \\
\hline $\mathrm{Y} 1.12$ & 0.306 & 0.177 & 0.663 & 0.463 & Valid \\
\hline Y1.13 & 0.223 & 0.309 & 0.602 & 0.433 & Valid \\
\hline $\mathrm{Y} 1.14$ & 0.504 & 0.378 & 0.723 & 0.598 & Valid \\
\hline $\mathrm{Y} 2.1$ & 0.522 & 0.282 & 0.820 & 0.856 & Valid \\
\hline Y2.2 & 0.526 & 0.168 & 0.664 & 0.912 & Valid \\
\hline Y2.3 & 0.525 & 0.077 & 0.618 & 0.935 & Valid \\
\hline Y2.4 & 0.536 & 0.111 & 0.665 & 0.942 & Valid \\
\hline Y2.5 & 0.535 & 0.168 & 0.598 & 0.899 & Valid \\
\hline Y2.6 & 0.615 & 0.188 & 0.629 & 0.904 & Valid \\
\hline
\end{tabular}

Based on the results of discriminant validity testing after modification of the model as shown in Table 4 and Table 5 above, it shows that all indicators have a cross loading value to the construct greater than the value of cross loading to other constructs, so that it is declared valid. It can be concluded that the construct of internal factors, external factors, entrepreneurship cognition and entrepreneurship intention has a good discriminant validity.

\section{Evaluation of the Structural Model (Inner Model) or Hypothesis Test Evaluate the Path Coefficient}

To evaluate the path coefficient, based on the calculation using SmartPLS version 3.2.7 bootstrapping, the path coefficient results illustrate the strength of the relationship between constructs / variables as shown in Figure 9 and Figure 10 and also Table 4. 


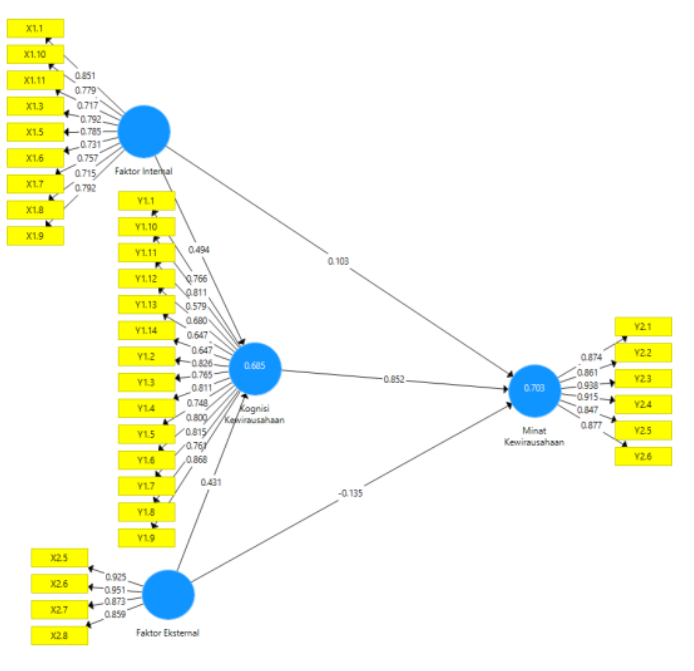

Figure 10. Calculation results for path coefficient Measurement Model (Inner Model) Mercu Buana University

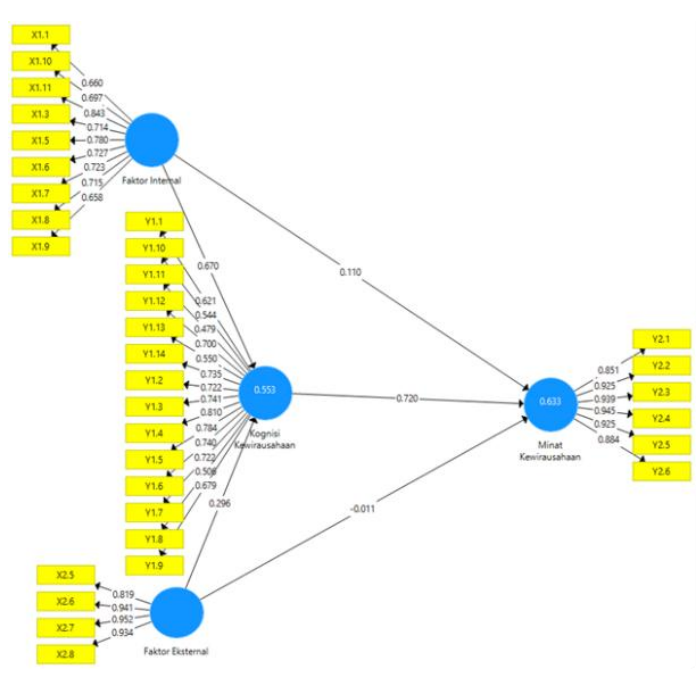

Figure 11. Calculation results for path coefficient Measurement Model (Inner Model) Bina Nusantara University

Table 7. Path Coefficient Test Results

\begin{tabular}{|c|c|c|c|c|c|c|}
\hline Path & $\begin{array}{c}\text { Original } \\
\text { Sample } \\
(0)\end{array}$ & $\begin{array}{c}\text { Sample } \\
\text { Mean } \\
(\mathrm{M}) \\
\end{array}$ & $\begin{array}{l}\text { Standard } \\
\text { Deviation } \\
\text { (STDEV) }\end{array}$ & $\begin{array}{l}\text { T Statistics } \\
(\mid \mathrm{O} / \mathrm{STDEV})\end{array}$ & $\begin{array}{c}\mathbf{T} \\
\text { Tabel }\end{array}$ & $\begin{array}{c}\mathbf{P} \\
\text { Values }\end{array}$ \\
\hline \multicolumn{7}{|c|}{ Mercu Buana University } \\
\hline $\begin{array}{l}\text { Internal Factor -> Entrepreneurship } \\
\text { Cognition }\end{array}$ & 0.494 & 0.494 & 0.089 & 5.549 & 2.003 & 0.000 \\
\hline $\begin{array}{l}\text { Internal Factor -> Entrepreneurship } \\
\text { Intention }\end{array}$ & 0.103 & 0.090 & 0.141 & 0.730 & 2.003 & 0.466 \\
\hline $\begin{array}{l}\text { External Factor -> Entrepreneurship } \\
\text { Cognition }\end{array}$ & 0.431 & 0.425 & 0.088 & 4.923 & 2.003 & 0.000 \\
\hline $\begin{array}{l}\text { External Factor -> Entrepreneurship } \\
\text { Intention }\end{array}$ & -0.135 & -0.134 & 0.142 & 0.947 & 2.003 & 0.344 \\
\hline $\begin{array}{l}\text { Entrepreneurship Cognition -> } \\
\text { Entrepreneurship Intention }\end{array}$ & 0.852 & 0.853 & 0.144 & 5.091 & 2.003 & 0.000 \\
\hline \multicolumn{7}{|c|}{ Bina Nusantara University } \\
\hline $\begin{array}{l}\text { Internal Factor -> Entrepreneurship } \\
\text { Cognition }\end{array}$ & 0.670 & 0.678 & 0.066 & 10.158 & 2.003 & 0.000 \\
\hline $\begin{array}{l}\text { Internal Factor -> Entrepreneurship } \\
\text { Intention }\end{array}$ & 0.110 & 0.110 & 0.148 & 0.743 & 2.003 & 0.458 \\
\hline $\begin{array}{l}\text { External Factor -> Entrepreneurship } \\
\text { Cognition }\end{array}$ & 0.296 & 0.297 & 0.094 & 3.143 & 2.003 & 0.002 \\
\hline $\begin{array}{l}\text { External Factor -> Entrepreneurship } \\
\text { Intention }\end{array}$ & -0.011 & -0.018 & 0.086 & 0.125 & 2.003 & 0.900 \\
\hline $\begin{array}{l}\text { Entrepreneurship Cognition -> } \\
\text { Entrepreneurship Intention }\end{array}$ & 0.720 & 0.729 & 0.105 & 6.872 & 2.003 & 0.000 \\
\hline
\end{tabular}

Source : Researcher processed data (2020)

Table 7 shows that the pathway that has the greatest influence is the path of entrepreneurship cognition to entrepreneurship intention, while the pathway that has the least influence is the path of external factors to entrepreneurship intention. The path coefficient results are valid for Mercu Buana University and Bina Nusantara University.

Evaluate the value of $\mathbf{R}^{2}$

$\mathrm{R}^{2}$ values indicate the level of determination of Exogenous Variables (Internal Factors and External Factors) towards Endogenous Variables (Entrepreneurship Cognition and Entrepreneurship 
Interest). There are 3 criteria for the value of $\mathrm{R}^{2}$, namely: 0.67 means strong, 0.33 means moderate and 0.19 means weak. As for the simultaneous influence of internal factor variables, external factors on entrepreneurship cognition can be done by calculating $\mathrm{f}$ arithmetic / $\mathrm{f}$ statistics using the formula as below. The results of the $\mathrm{R}^{2}$ and $\mathrm{F}$ values are shown in Table 8

$\mathrm{F}$ hitung $=\frac{\frac{\mathrm{R}^{2}}{\mathrm{k}-1}}{\frac{1-\mathrm{R}^{2}}{\mathrm{n}-\mathrm{k}}} \quad \mathrm{k}=$ jumlah variabel, $\mathrm{n}=$ jumlah sampel

Table 8. Path Coefficient Test Results (Path Coefficient)

\begin{tabular}{|c|c|c|c|c|c|c|c|c|}
\hline \multirow[b]{2}{*}{ Path } & \multicolumn{4}{|c|}{ Mercu Buana University } & \multicolumn{4}{|c|}{ Bina Nusantara University } \\
\hline & R Square & $\begin{array}{l}\text { R Square } \\
\text { Adjusted }\end{array}$ & $\begin{array}{c}\text { F } \\
\text { Hitung }\end{array}$ & $\begin{array}{c}\mathbf{F} \\
\text { Tabel }\end{array}$ & $\begin{array}{c}\mathbf{R} \\
\text { Square }\end{array}$ & $\begin{array}{c}\text { R } \\
\text { Square } \\
\text { Adjusted }\end{array}$ & $\begin{array}{c}\text { F } \\
\text { Hitung }\end{array}$ & $\begin{array}{c}\text { F } \\
\text { Tabel }\end{array}$ \\
\hline $\begin{array}{l}\text { Entrepreneurship } \\
\text { Cognition }\end{array}$ & 0.685 & 0.674 & 40.57 & 2.77 & 0.553 & 0.538 & 23.00 & 2.77 \\
\hline $\begin{array}{l}\text { Entrepreneurship } \\
\text { Intention }\end{array}$ & 0.703 & 0.687 & 44.15 & 2.77 & 0.633 & 0.613 & 32.46 & 2.77 \\
\hline
\end{tabular}

Source : Researcher processed data (2020)

Table 7 shows the level of determination of exogenous variables on endogenous variables at Mercu Buana University is categorized as strong in all paths, while the level of determination of exogenous variables on endogenous variables at Bina Nusantara University is categorized as moderate on all paths

\section{Measuring Effect Size $\mathbf{f}^{2}$}

The purpose is to measure the effect size $\mathrm{f}^{2}$ to see the size of the effect of exogenous latent variables on endogenous latent variables or to see the goodness of the model. There are 3 criteria for the value of $f^{2}$ : 0.35 means strong, 0.15 means moderate and 0.12 means weak. The results of calculating the effect size (f square) value with Smart PLS version 3.2.7 are in table 9 below.

Tabel 9. Nilai Effect Size $\mathbf{F}^{2}$

\begin{tabular}{lcccc}
\hline \multirow{2}{*}{ Variable } & \multicolumn{2}{c}{ Mercu Buana University } & \multicolumn{2}{c}{ Bina Nusantara University } \\
\cline { 2 - 5 } & $\begin{array}{c}\text { Entrepreneurship } \\
\text { Cognition }\end{array}$ & $\begin{array}{c}\text { Entrepreneurship } \\
\text { Intention }\end{array}$ & $\begin{array}{c}\text { Entrepreneurship } \\
\text { Cognition }\end{array}$ & $\begin{array}{c}\text { Entrepreneurship } \\
\text { Intention }\end{array}$ \\
\hline Internal Factor & 0.497 & 0.015 & 1.002 & 0.016 \\
\hline External Factor & 0.379 & 0.028 & 0.196 & 0.000 \\
\hline $\begin{array}{l}\text { Entrepreneurship } \\
\text { Cognition }\end{array}$ & & 0.769 & & 0.630 \\
\hline
\end{tabular}

Source : Researcher processed data (2020)

Table 9 shows that internal factors and external factors have a strong influence on the structural level of entrepreneurship cognition variables. In addition, entrepreneurship cognition has a strong influence on the structural level of entrepreneurship interntion variables (Mercu Buana University), and internal factor variables have a strong influence on the structural level of entrepreneurship cognition variables and also entrepreneurship cognition variables have a strong influence on the structural level towards entrepreneurship intention variable (Bina Nusantara University).

\section{Validate the Overall Structural Model with Goodness of Fit Index (GoF) and Predictive Relevance $\left(\mathbf{Q}^{2}\right)$}

The purpose of testing the Goodness of Fit Index (GoF) is to validate the combined performance of the measurement model (outer model) and structural model (inner model). The provisions of the GoF category are small $\mathrm{GoF}$ values $=0.1$, medium $\mathrm{GoF}=0.25$ and large $\mathrm{GoF}=$ 0.36 . GoF calculation is done by the following formula. 


$$
\mathrm{GoF}=\sqrt{\mathrm{AVE} * \mathrm{R}^{2}}
$$

The purpose of testing predictive relevance $\left(\mathrm{Q}^{2}\right)$ is to validate the model. If endogenous latent variables have predictive relevance $\left(\mathrm{Q}^{2}\right)$ values greater than 0 (zero), then exogenous latent variables can be considered capable of predicting endogenous variables or it can be said that this model is considered to have good predictive relevance. $\mathrm{Q}^{2}$ calculations are carried out with the following formula. The results of the $\mathrm{GoF}$ and $\mathrm{Q}^{2}$ calculations are shown in Table 10.

$$
\mathrm{Q}^{2}=1-\left(1-\mathrm{R}_{1}^{2}\right)\left(1-\mathrm{R}_{2}^{2}\right)
$$

Tabel 10. Hasil Pengujian GoF dan $Q^{2}$

\begin{tabular}{llccc}
\hline & \multicolumn{2}{c}{ Mercu Buana University } & \multicolumn{2}{c}{ Bina Nusantara University } \\
\hline Measurement type & GoF & $\mathrm{Q}^{2}$ & GoF & $\mathrm{Q}^{2}$ \\
\hline Calculation Result & 0.394 & 0.907 & 0.465 & 0.836 \\
\hline Interpretation & Large & Good & Large & Good \\
\hline \multicolumn{1}{c}{ Source : Researcher processed data (2020) } & & &
\end{tabular}

Table 10 shows that the Mercu Buana University Goodness of Fit Index (GoF) calculation results show the value of 0.394 . Based on these results it can be concluded that the combined performance of the measurement model (outer model) and structural model (inner model) is a large GoF, because the Goodness of Fit Index (GoF) value is more than 0.36 (large scale GoF). The results of the Bina Nusantara University Goodness of Fit Index (GoF) calculation showed a value of 0.465. Based on these results it can be concluded that the combined performance of the measurement model (outer model) and structural model (inner model) is a strong GoF, because the Goodness of Fit Index (GoF) value is more than 0.36 (large scale GoF).

The results of the predictive relevance $\left(\mathrm{Q}^{2}\right)$ calculation show each value is 0.907 for Mercu Buana University and 0.836 for Bina Nusantara University. In this research model, endogenous latent variables have predictive relevance $\left(\mathrm{Q}^{2}\right)$ values greater than 0 (zero) so that exogenous latent variables as explanatory variables are able to predict their endogenous variables namely entrepreneurship intention or in other words prove that this model is considered to have good predictive relevance, both at Mercu Buana University and Bina Nusantara University.

\section{Results of the Effect of Independent Variables on Dependent Variables}

The statistical calculation results of the influence of the independent variables on the dependent variable are presented in Table 11, Table 12 and Table 13 To simplify, researchers use the abbreviation IF for the Internal Factor variable, the EF abbreviation for the External Factor variable, the abbreviation EC for Entrepreneurship Cognition and EC for entrepreneurship intention.

Table 11 presents the results of the test of the influence of significance between the two variables. Measuring instruments used are path coefficients, comparison of $\mathrm{T}$ arithmetic with $\mathrm{T}$ table and also the comparison of P Calculate and P Standard. If the calculated T arithmatic is greater than the $\mathrm{T}$ table and the $\mathrm{P}$ arithmatic is smaller than the $\mathrm{P}$ standard, then the hypothesis is accepted. Vice versa. A more complete explanation of Table 10 will be explained in the discussion section.

Tabel 11. Result of the effect of Independent Variables on Dependent Variables (Part I)

\begin{tabular}{|l|c|c|c|c|c|}
\hline Hypothesis & Interpretation & $\begin{array}{c}\text { Coefficient } \\
\text { Path }\end{array}$ & $\begin{array}{c}\text { T arithmatic }> \\
\text { T table }\end{array}$ & $\begin{array}{c}\text { P arithmetic } \\
\text { (Compared with } \\
\text { P Standard } \\
\text { 0.05) }\end{array}$ & Conclusion \\
\hline $\mathrm{H}_{1.1}$ & $\begin{array}{c}\text { IF has a significant effect on EC } \\
\text { at UMB }\end{array}$ & 0.494 & $5.549>2.003$ & 0.000 & Received \\
\hline $\mathrm{H}_{1.2}$ & $\begin{array}{c}\text { IF has a significant effect on EC } \\
\text { at Binus }\end{array}$ & 0.670 & $10.158>2.003$ & 0.000 & Received \\
\hline $\mathrm{H}_{2.1}$ & $\begin{array}{c}\text { EF has a significant effect on EC } \\
\text { at UMB }\end{array}$ & 0.431 & $4.923>2.003$ & 0.000 & Received \\
\hline $\mathrm{H}_{2.2}$ & $\begin{array}{c}\text { EF has a significant effect on EC } \\
\text { at Binus }\end{array}$ & 0.296 & $3.143>2.003$ & 0.002 & Received \\
\hline
\end{tabular}




\begin{tabular}{|l|c|c|c|c|c|}
\hline Hypothesis & Interpretation & $\begin{array}{c}\text { Coefficient } \\
\text { Path }\end{array}$ & $\begin{array}{c}\text { T arithmatic }> \\
\text { T table }\end{array}$ & $\begin{array}{c}\text { P arithmetic } \\
\text { (Compared with } \\
\text { P Standard } \\
\mathbf{0 . 0 5})\end{array}$ & Conclusion \\
\hline $\mathrm{H}_{3.1}$ & $\begin{array}{c}\text { IF has a significant effect on EI } \\
\text { at UMB }\end{array}$ & 0.103 & $0.730<2.003$ & 0.466 & Rejected \\
\hline $\mathrm{H}_{3.2}$ & $\begin{array}{c}\text { IF has a significant effect on EI } \\
\text { at Binus }\end{array}$ & 0.110 & $0.743<2.003$ & 0.458 & Rejected \\
\hline $\mathrm{H}_{4.1}$ & $\begin{array}{c}\text { EF has a significant effect on EI } \\
\text { at UMB }\end{array}$ & -0.135 & $0.947<2.003$ & 0.344 & Rejected \\
\hline $\mathrm{H}_{4.2}$ & $\begin{array}{c}\text { EF has a significant effect on EI } \\
\text { at Binus }\end{array}$ & -0.011 & $0.125<2.003$ & 0.900 & Rejected \\
\hline $\mathrm{H}_{5.1}$ & $\begin{array}{c}\text { EC has a significant effect on EI } \\
\text { at UMB }\end{array}$ & 0.852 & $5.091>2.003$ & 0.000 & Received \\
\hline $\mathrm{H}_{5.2}$ & $\begin{array}{c}\text { EC has a significant effect on EI } \\
\text { at Binus }\end{array}$ & 0.720 & $6.872>2.003$ & 0.000 & Received \\
\hline
\end{tabular}

Table 12 presents the results of the simultaneous influence test between variables. The measuring instrument used is $\mathrm{R}$ Square and also the comparison of F arithmetic with F Table. If the calculated $\mathrm{F}$ arithmatic is greater than the $\mathrm{F}$ Table, then the hypothesis is accepted. Vice versa. A more complete explanation of Table 12 will be explained in the discussion section.

Table 12. Result of the effect of Independent Variables on Dependent Variables (Part II)

\begin{tabular}{|c|c|c|c|c|}
\hline Hypothesis & Interpretation & R Square & $\begin{array}{l}\text { F arithmatic }> \\
\text { F table }\end{array}$ & Conclusion \\
\hline $\mathrm{H}_{6.1}$ & $\begin{array}{l}\text { IF, EF has a significant effect on EC at } \\
\text { UMB }\end{array}$ & 0.685 (Kuat) & $40.57>2.77$ & Received \\
\hline $\mathrm{H}_{6.2}$ & $\begin{array}{c}\text { IF, EF has a significant effect on EC at } \\
\text { Binus }\end{array}$ & 0.553 (Moderat) & $23.00>2.77$ & Received \\
\hline $\mathrm{H}_{7.1}$ & $\begin{array}{c}\text { IF, EF, EC has a significant effect on EI } \\
\text { at UMB }\end{array}$ & 0.703 (Kuat) & $44.15>2.77$ & Received \\
\hline $\mathrm{H}_{7.2}$ & $\begin{array}{l}\text { IF, EF, EC has a significant effect on EI } \\
\text { at Binus }\end{array}$ & 0.633 (Moderat) & $32.46>2.77$ & Received \\
\hline
\end{tabular}

Source : Researcher processed data (2020)

Table 13 presents the results of the direct and indirect effects of the variables that influence entrepreneurship inntention at Mercu Buana University and Bina Nusantara University. The basis for making decisions to determine the functioning of mediator variables is as follows:

a. If the path coefficient between internal or external factors and entrepreneurship intention from the direct effect (DE) to the indirect effect (IE) does not change, then $\mathrm{H}_{0}$ is accepted and $\mathrm{H}_{8}$ is rejected.

b. If the path coefficient between internal or external factors and entrepreneurship intention from the direct effect (DE) to the indirect effect (IE) decreases, then $\mathrm{H}_{0}$ is accepted and $\mathrm{H}_{8}$ is rejected.

c. If the path coefficient between internal factors or external factors and entrepreneurship intention from the direct effect (DE) to the indirect effect (IE) increases in value, then $\mathrm{H}_{0}$ is rejected and $\mathrm{H}_{8}$ is accepted.

A fuller explanation of Table 14 will be explained in the discussion section.

Table 13. Result of the effect of Independent Variables on Dependent Variables (Part III)

\begin{tabular}{|c|c|c|c|c|c|c|}
\hline Hypothesis & Interpretation & Direct Effect (DE) & \multicolumn{2}{|c|}{ Indirect Effect (IE) } & IE>DE \\
\hline \multirow{2}{*}{$\mathrm{H}_{8.1}$} & $\begin{array}{c}\text { EC mediates IF, } \mathrm{EF} \\
\text { to EI at UMB }\end{array}$ & FI $>\mathrm{MW}=\mathbf{0 . 1 0 3}$ & FI $>\mathrm{KW}=0.494$ & $\mathrm{KW}>\mathrm{MW}=0.852$ & $\mathbf{0 . 4 2 1}$ & Received \\
\cline { 3 - 8 } & & $\mathrm{FE}>\mathrm{MW}=\mathbf{- 0 . 1 3 5}$ & $\mathrm{FE}>\mathrm{KW}=0.431$ & $\mathrm{KW}>\mathrm{MW}=0.852$ & $\mathbf{0 . 3 6 7}$ & Received \\
\hline \multirow{2}{*}{$\mathrm{H}_{8.2}$} & $\begin{array}{c}\text { EC mediates IF, } \mathrm{EF} \\
\text { to EI at Binus }\end{array}$ & $\mathrm{FI}>\mathrm{MW}=\mathbf{0 . 1 1 0}$ & $\mathrm{FI}>\mathrm{KW}=0.670$ & $\mathrm{KW}>\mathrm{MW}=0.720$ & $\mathbf{0 . 4 8 2}$ & Received \\
\cline { 3 - 8 } & & $\mathrm{FE}>\mathrm{MW}=\mathbf{- 0 . 0 1 1}$ & $\mathrm{FE}>\mathrm{KW}=0.296$ & $\mathrm{KW}>\mathrm{MW}=0.720$ & $\mathbf{0 . 2 1 3}$ & Received \\
\hline
\end{tabular}

Source : Researcher processed data (2020)

\section{Correlation Analysis Between Dimensions}

Correlation matrix between dimensions is intended to determine the dimensions of the independent variables (internal factors and external factors) which have the highest correlation value with the dependent variable dimensions Y1 (entrepreneurship cognition) and the dependent variable dimensions Y2 (entrepreneurship intention) and also to determine the dimensions of the dependent variable Y1 ( entrepreneurship cognition) which has the highest correlation value with the Y2 
dependent variable dimension (entrepreneurship intention). Correlations between dimensions are shown in Table 14.

Table 14. Correlation Matrix Results Between Dimensions of Independent Variables and Dependent Variables

\begin{tabular}{|c|c|c|c|c|c|c|c|c|c|c|c|c|}
\hline \multirow{2}{*}{ Dimension } & \multicolumn{6}{|c|}{ Mercu Buana University } & \multicolumn{6}{|c|}{ Bina Nusantara University } \\
\hline & Y11 & Y1.2 & Y1.3 & Y21 & Y22 & Y23 & Y11 & Y1.2 & Y1.3 & Y21 & Y22 & Y23 \\
\hline X11 & 0.290 & 0.492 & 0.267 & 0.234 & 0.326 & 0.349 & 0.473 & 0.334 & 0.199 & 0.436 & 0.453 & 0.435 \\
\hline $\mathrm{X} 12$ & 0.352 & 0.547 & 0.339 & 0.359 & 0.394 & 0.432 & 0.546 & 0.342 & 0.233 & 0.532 & 0.461 & 0.510 \\
\hline $\mathrm{X} 22$ & 0.471 & 0.531 & 0.346 & 0.371 & 0.384 & 0.341 & 0.248 & 0.153 & 0.158 & 0.210 & 0.104 & 0.176 \\
\hline Y11 & & & & 0.580 & 0.607 & 0.455 & & & & 0.694 & 0.580 & 0.569 \\
\hline Y12 & & & & 0.455 & 0.529 & 0.482 & & & & 0.433 & 0.353 & 0.334 \\
\hline Y13 & & & & 0.340 & 0.423 & 0.435 & & & & 0.473 & 0.436 & 0.448 \\
\hline
\end{tabular}

Explanation :

X1.1: Personal Character

$\mathrm{X} 1.2$ : Experience

X2.1: Capital

$\mathrm{X} 2.2$ : Entrepreneurship Education

Y1.1: Attitude toward entrepreneurship

Y1.2: Subjective Norms

Y1.3 : Perception Control Behavior

Y2.1: Desire

Y2.2: Self Prediction

Y2.3: Behavioral Intention

\section{Discussion}

Hypothesis Test Results show that Internal Factors significantly influence entrepreneurship cognition, both at Mercu Buana University and Bina Nusantara University. This shows that the personal characteristics and experiences gained by students significantly affect the entrepreneurship mindset that students have. The more students have strong personal characteristics and also positive experiences about entrepreneurship, both experienced by themselves and the people they know, the more positive mindset of entrepreneurship that they have.

Hypothesis Test Results also show that External Factors significantly influence entrepreneurship cognition, both at Mercu Buana University and Bina Nusantara University. This shows that entrepreneurship education, both the curriculum and the extracurricular activities received significantly effect the mindset of entrepreneurship students have. The more students get adequate entrepreneurship education, both in quality and quantity, the more positive the entrepreneurship mindset that exists within them

Hypothesis Test Results also show that entrepreneurship cognition has a significant effect on entrepreneurship intention, both at Mercu Buana University and Bina Nusantara University. This shows that the more positive the entrepreneurship mindset that exists in themselves, the higher the intention to become entrepreneurs.

Hypothesis Test Results also show that internal and external factors do not significantly influence entrepreneurship intention directly, both at Mercu Buana University and Bina Nusantara 
University. This is because the process of self-recognition of theirs character, lesson learned from the entrepreneurship experience by theirself or others have done, as well as entrepreneurship education obtained at school cannot necessarily be able to decide whether to become an entrepreneur or not. Respondents need to manage all these assessments into more specific considerations, namely what if he uses all the character, experience and education he gets to become an entrepreneur, whether the entrepreneurship choice will give the best results than other choices, whether they can get support from his social connection and whether he is able to start and develop a business with all available inputs. Based on this explanation, we can conclude that self-input (both internal and external factors) does not significantly influence entrepreneurship intention because all these inputs need to be processed first in specific considerations in entrepreneurship cognition.

The Hypothesis Test Results also showed that the variables of Internal Factors and External Factors simultaneously had a significant effect on the variables of entrepreneurship cognition at Mercu Buana University with a simultaneous influence of $68.5 \%$, while the remaining $31.5 \%$ of entrepreneurship cognition was influenced by other factors, whereas at Bina Nusantara University, the influence is simultaneously equal to $55.3 \%$, while the remaining $44.7 \%$ entrepreneurship cognition is influenced by other factors outside of internal factors and external factors. Based on these results, the researchers concluded that personal characteristics and entrepreneurship experience had a significant influence on entrepreneurship cognition at Mercu Buana University and Bina Nusantara University.

The Hypothesis Test Results also showed that the variables of Internal Factors, External Factors and Entrepreneurship Cognition simultaneously had a significant effect on the variables of entrepreneurship intention at Mercu Buana University with a simultaneous influence of $70.3 \%$, while the remaining $29.7 \%$ entrepreneurs interest was influenced by factors other. While its influence at Bina Nusantara University, the influence was simultaneously equal to $63.3 \%$, while the remaining $36.7 \%$ entrepreneurship intention was influenced by other factors. Based on these results, the researcher concludes that personal characteristics, entrepreneurship experience and entrepreneurship cognition have a significant effect on entrepreneurship intention at Mercu Buana University.

Hypothesis Test Results also show that entrepreneurship cognition variables can mediate the influence of internal factors or external factors on entrepreneurship intention, both at Mercu Buana University and at Bina Nusantara University. Based on this, the researcher concluded that all the factors that exist in students, both internal and external factors in the form of personal characteristics, experience and entrepreneurship education received by students are processed cognitively first before they decide whether or not they are interested in becoming entrepreneurs.

Correlation Test results show a slight difference between Mercu Buana University and Bina Nusantara University. At Mercu Buana University, the dimensions of personal character, experience and entrepreneurship education have the highest correlation with subjective norms. In addition, attitudes toward entrepreneurship and subjective norms have the highest correlation with selfprediction in the future. And also, the perception of behavioral control has the highest correlation with the behavioral intention.

The results of these correlations can provide conclusions that a person's assessment of their character and the quality of entrepreneurship education and experience gained will be very closely related to the support of the relationship to their choice to become an entrepreneur. Furthermore, the perception of the results obtained from entrepreneurship and also the support obtained for entrepreneurship will be closely related to the choice of entrepreneurship as a career. Furthermore, their self-assessment of being able or not to open and develop a business is closely related to whether or not the entrepreneurhip activity will really be done. The more confident they has ability to have a business, the more likely they become an entrepreneur.

At Bina Nusantara University, dimensions of personal character, experience and entrepreneurship education have the highest correlation with entrepreneurship attitudes. In addition, attitudes towards entrepreneurship, subjective norms and perceptions of behavioral control have the highest correlation with future desires.

The results of these correlations can provide conclusions that a person's assessment of their own character and the quality of entrepreneurship education and experience gained will be very 
closely related to the assessment of the results obtained from entrepreneurship. The more they believes he has a strong mentality and his education and experience is sufficient for entrepreneurship, the more confident he becomes with the choice of being an entrepreneur, and the prediction that the entrepreneurship will provide optimal results is also getting stronger. In addition, perception of the results of business that will be gained, support relations that will be achieved and also self ability in entrepreneurship will confirm that their professional goal is to become an entrepreneur and they will truly make a business in the future.

\section{CONCLUSIONS AND RECOMMENDATIONS Conclusion}

Based on the results of previous studies and discussions, several conclusions can be made, namely: (1) internal factors have a significant positive effect on entrepreneurship cognition, both at Mercu Buana University and Bina Nusantara University, (2) external factors have a significant positive effect on entrepreneurship cognition, both at Mercu University Buana and Bina Nusantara University, (3) internal factors have no significant positive effect on entrepreneurship intention, both at Mercu Buana University and Bina Nusantara University, (4) external factors have no significant positive effect on entrepreneurship intention, both at Mercu Buana University and Bina University Nusantara, (5) entrepreneurship cognition as a mediator in this study has a significant effect on entrepreneurship intention, both at Mercu Buana University and Bina Nusantara University (6) internal and external factors together have a significant positive effect on entrepreneurship cognition, both at Mercu Buana University and Bina Nusantara University, (7) internal factors, external factors and entrepreneurship cognition simultaneously have a positive and significant influence on entrepreneurship intention, both at Mercu Buana University and Bina Nusantara University, (8) Entrepreneurship cognition mediates internal and external factors towards entrepreneurship intention, both at Mercu Buana University and Bina Nusantara University

\section{Suggestion}

Based on the results of these correlations, the suggestions that can be given to complete the results of this study are as follows:

1. For Institution

a. Institutions need to ensure that the entrepreneurship education process carried out can increase student interest for being entrepreneur. These interests can be formed by continuously provide an understanding that the results of entrepreneurship in their intererested kind businness can provide financial and non-financial results that are better than if they become an employee.

b. Institutions need to conduct comprehensive entrepreneurship education that can improve mental character, knowledge and skills to become entrepreneurs that are tailored to each student profiles.

The initial step, the institution can conduct an initial assessment (example character, background, type of interested business, and other if necessary). The results of the assessment will be a database for institution, then can be followed up with entrepreneurship education in accordance with each student's specialization. This assessment can also be used to determine the teaching component that is able to attract the desire to explore entrepreneurship, by providing educators, materials and learning objectives that make student interest on it. Institutions can also do character building, provisioning basic skills of entrepreneurs and also a variety of business experiences to enrich experience for trial errors to become entrepreneurs. Hopefully, the end result of entrepreneurship education can foster confidence in students that they are able to become entrepreneurs.

c. Institutions need to provide entrepreneurship education in a systematic pathways so that students' achievements are monitored gradually and also need certification or special recognition which states that students are competent to become entrepreneurs. This is to ensure that students have a strong perception that they are able to become entrepreneurs so that their tendency to act to become an entrepreneur is also higher. 
d. Curriculum, gradual achievement and final results of entrepreneurship education should be communicated to parents / guardians or published extensively through the university's information portal so that students increasingly receive support from family, friends and colleagues to become entrepreneurs.

2. For Further Researchers

Suggestions from researchers for future researchers are:

a. Sampling scope

Samples can be carried out more thoroughly in several universities, so that a more comprehensive explanation of entrepreneurship intention is known. Researchers in this study have taken two private universities as research samples. Henceforth, research can take a sample of state universities, a sample of several universities in a particular city in order to provide a general picture of student entrepreneurship intention.

b. Focus on effective and efficient entrepreneurship education

This advice is given so that research can have a significant impact on education. Researchers can focus on entrepreneurship education matter and also can compare the existing entrepreneurship education system on benchmark campuses with proven track record in creating a number of reliable entrepreneurs, both domestic and abroad.

\section{BIBLIOGRAPHY}

Adhimursandi D, Faktor-Faktor Yang Mempengaruhi Niat Kewirausahaan, Jurnal Ekonomi dan Manajemen, 2016, 13 (1), 193-210

Aima, Susilo, Purwanto, Wiratih. Entrepreneurship dan Peluang Usaha Menyusun business plan yang unggul dan inspiratif. Jakarta: Penerbit In Media. 2015

Aima MH, Wijaya SA, Carawangsa L, Ying M, Effect of Global Mindset and Entreprenerial Motivation to Entrepreneurship Self-Efficacy and Implication to Entrepreneurship Intention, Dinasti International Journal of Digital Businness Management (DIJDBM), 2020, 1(2), 302-314

Anas I, Lembaga Pengembangan Keterampilan Dan Kewirausahaan (LPK2) Dalam Mengembangkan Wirausaha Santri Di Pondok Pesantren Wahid Hasyim Yogyakarta, Jurnal Pendidikan Luar Sekolah, 2018, 7 (7), 824-829

Ambad SNA, Damit DHDA, Determinants of Entrepreneurship Intention among Undergraduate Students in Malaysia, Economic and Finance, 2016, 37 (1), 108-114

Amir N, Sjahruddin H, Razak N, Faktor-Faktor Yang Mempengaruhi Intensi Berwirausaha Pada Mahasiswa Program Studi Manajemen STIEM Bongaya, 2017 Sept, 1(1), 1-13

Bogatyreva K, Edelman LF, Manolova TS, Osiyevskyy O, Shirokova G, When do entrepreneurship intentions lead to actions? The role of national culture, Journal of Businness Research, 2019, 96 (1), 309-321

BPS. (2019). Februari 2019 : Tingkat pengangguran Terbuka (TPT) sebesar 5,01 Persen (online). (https://www.bps.go.id/pressrelease/2019/05/06/1564/februari-2019--tingkat-pengangguranterbuka--tpt--sebesar-5-01-persen.html, diakses pada 8 oktober 2019)

Dharmawati. Kewirausahaan. Depok: Raja Grafindo Persada. 2017

Din B, Anuar AR, Usman M, The Effectiveness of the Entrepreneurship Education Program in Upgrading Entrepreneurship Skills among Public University Students, Social and Behavioral Sciences, 2015, 224 (1), 117-123

DPR. [Tanpa Judul]. http://www.dpr.go.id/doksileg/proses1/RJ1-20151210-040422-7678.pdf, [diakses pada 8 oktober 2019]

Edelman LF, Manolova T, Shirokova G, Tsukanova T, The Impact of family support on young start up activities, Journal of Businness Venturing, 2016, 31 (1), 428-448

Effendy JA, Eksplorasi Faktor-Faktor Pendorong Keputusan Untuk Menjadi Seorang Hybrid Entrepreneur pada Alumni Universitas Ciputra, DeReMa Jurnal Manajemen. 2018 Sept; 13 (2) 
Esfandiara K, Sharifi-Tehrani M, Pratt S, Altinay L, Understanding entrepreneurship intentions: A developed integrated structural model approach, Journal of Businness Research, 2019, 94 (1), 172182

Fayolle A, Linan F, The future of research on etrepreneurial intention, Journal of Businness Research, 2014, 67 (1), 663-666

Fuller B, Liu Y, Bajaba S, Marler LE, Pratt J, Examining how the personality, self-efficacy, and anticipatory cognitions of potential entrepreneurs shape their entrepreneurship intentions, Personality and individual differerences, 2018, 125 (1), 120-125

Galanakis K, Entrepreneurship path: decoupling the complexity of entrepreneurship process, International Journal of Entrepreneurship Bbehavior and Research, 2017, 23 (2), 317-335

Ghozali I, Latan H. (2015). Partial Least Squares: Konsep, Teknik dan Aplikasi Menggunakan Program SmartPLS 3.0 Untuk Penelitian Empiris. Semarang: Badan Penerbit Undip

Hisrich RD, Peters MP, Shepherd DA. (2013). Entrepreneurship. Singapore:McGraw-Hill Irwin

Hsu DK, Burmeister-Lamp K, Simmons SA, Foo M, Hong MC, Pipes JD, "I know I can, but I don't fit”: Perceived fit, self-efficacy, and entrepreneurship intention, Journal of Businness Venturing, 2019, 34 (1), 311-326

Karabulut AT, Personality Traits on Entrepreneurship Intention, Social and Behavioral Sciences, 2016, 229 (1), $12-21$

Kompas. Kenapa Lulusan Perguruan Tinggi Makin Susah Mendapat Pekerjaan?, https://edukasi.kompas.com/read/2016/04/23/17424071/Kenapa.Lulusan.Perguruan.Tinggi.Makin. Susah.Mendapat.Pekerjaan?page=all. [diakses pada 7 oktober 2019]

Lackeus M, An emotional based approach to assessing entrepreneurship education, The International Journal of Management Education, 2014, 12 (1), 374-396

Laguia A, Moriano JA, Gorgievski MJ, A psychosocial study of self-perceived creativity and entrepreneurship intentions in a sample of university students, Thinking Skills and Creativity, 2019, 31 (1), 44-57

Liguori EW, Bendickson JS, McDowell WC, Revisiting entrepreneurship intentions: a social cognitive career theory approach, International Enterpreneur Management Journal, 2018, 14 (1), 67-78

Mat SC, Maat SM, Mohd N, Identifying Factors that Affecting the Entrepreneurship Intention among Engineering Technology Students, Social and Behavioral Sciences, 2015, 211 (1), 1016-1022

Mustaqim M, Membangun Intensi Wirausaha Mahasiswa: Studi Pada Mahasiswa Prodi MBS Dan ES STAIN Kudus. Jurnal Ekonomi Syariah. 2017; 5 (1): 134-149

Newbery R, Lean J, Moizer J, Haddoud M, Entrepreneurship identity formation during the initial entrepreneurship experience: The influence of simulation feedback and existing identity, Journal of Businness Research, 2018, 85 (1), 51-59

Nowinskia W, Haddoud MY, The role of inspiring role models in enhancing entrepreneurship intention, Journal of Businness Research, 2019, 96(1), 183-193

Periyadi, Junaidi, Pengaruh Faktor Internal Dan Eksternal Terhadap Minat Berwirausaha Pada Mahasiswa Fakultas Ekonomi Universitas Islam Kalimantan (Uniska) Muhammad Arsyad Albanjary Banjarmasin, 2019 Sept, 12(2), 231-249

Pratiwi Y, Wardana IM, Pengaruh Faktor Internal Dan Eksternal Terhadap Minat Berwirausaha Mahasiswa Fakultas Ekonomi Dan Bisnis Universitas Udayana, E Jurnal Manajemen Unud, 2016, 5 (8), 5215-524.

Putri NLWW, Pengaruh Pendidikan Kewirausahaan Terhadap Minat Mahasiswa Untuk Berwirausaha Pada Mahasiswa Pendidikan Ekonomi Universitas Pendidikan Ganesha, Jurnal Pendidikan Ekonomi Undiksha, 2017, 9 (1), 137-148 
Rahmadi AN, Heryanto B, Analisis Faktor-Faktor Yang Mempengaruhi Minat Berwirausaha Pada Mahasiswa Program Studi Manajemen Fakultas Ekonomi Universitas Kadiri, Jurnal Ekonomi Universitas Kadiri, 2016 Sept, 1 (2), 153 - 169

Republika, RI Butuh Jutaan Wirausaha Baru, http://www.republika.co.id/berita/koran/ ekonomikoran/16/05/24/o7oh8614-ri-butuhjutaan-wirausaha-baru, [diakses pada 7 oktober 2019]

Rosmiati, Junias DTS, Munawar. Sikap, Motivasi, Dan Minat Berwirausaha Mahasiswa. Jurnal Manajemen dan Kewirausahaan. 2015 Mar; 17(1): 21-30

Saiman. (2009). Kewirausahaan Teori, Praktik dan Kasus-Kasus. Jakarta: Salemba Empat

Saiman. (2016). Kewirausahaan Teori, Praktik dan Kasus-Kasus. Jakarta: Salemba Empat

Santoso S, Oetomo BSD. Pengaruh motivasi dan efikasi diri terhadap minat membuka start-up business pada mahasiswa. In: Prosiding Seminar Hasil Penelitian bagi Civitas Akademika UKDW "Peran Hasil Penelitian Perguruan Tinggi dalam Menunjang Pembangunan Masyarakat", 17 November 2017, Indonesia. Yogyakarta: Universitas Kristen Duta Wacana; 2017. p.214-227.

Suarjana AAGM, Wahyuni LM, Faktor Penentu Minat Berwirausaha Mahasiswa (Suatu Evaluasi Pembelajaran), Jurnal Bisnis dan Kewirausahaan, 2017 Mar, 13 (1)

Sugiarto J, Wismanto YB, Utami CT, Efektivitas Pelatihan Entrepreneurship Skill Untuk Meningkatkan Minat Menjadi Entrepreneur, Prediksi, Kajian Ilmiah Psikologi . 2015 Jan-Jun; 1 (4): 51-60

Tuan NA, Ha DTH , Thao VTB, Anh DK, Long NH, Factors aff ecting entrepreneurship intentions among youths in Vietnam, Children and Youth Services Review, 2019, 99 (1), 186-193

Walipah, Naim, Faktor - Faktor Yang Mempengaruhi Niat Berwirausaha Mahasiswa, Jurnal Ekonomi Modernisasi. 2016; 12 (3): 138-144

Wiyono G. (2011). Merancang Penelitian Bisnis dengan alat analisis SPSS 17.0 dan SmartPLS 2.0. Yogyakarta: STIM YPKN Yogyakarta 